\title{
Ağrı ilinde Sığırlarda Ayak Hastalıkları Prevalansının Belirlenmesi
}

\author{
Selvinaz YAKAN \\ Ağrı Ibrahim Çeçen Üniversitesi, Eleşkirt Celal Oruç Hayvansal Üretim Yüksek Okulu, Hayvan Sağlığı Anabilim Dalı, Ağrı, \\ Türkiye.
}

Gelis Tarihi: 20.06.2018

Kabul Tarihi: 03.12.2018

Özet: Bu çalışma; Ağıı ilinde sığırlarda görülen ayak hastalıklarının prevalansının belirlenmesi amacıyla yapıldı. Araştırma farklı ırk, yaş ve cinsiyette toplam 1486 sığır üzerinde yürütüldü. Araştırmadaki hayvanların ırklara göre dağılımı \%34.66 (515 olgu)'sı Montofon, \%30.96 (460 olgu)'sı Simental, \%24.02 (357 olgu)'si yerli ırk, \%10.36 (154 olgu)'sı melez sığırlardı. Olguların cinsiyete göre dağıımı ise \%84.45 (1255 olgu)'i dişi, \%15.55 (231 olgu)'i erkekti. 1486 sığırdan 280 sığırda ayak hastalığı tespit edildi. Tespit edilen hastalıkların \%29.45 (48 olgu)'i interdigital dermatitis, \%23.31 (38 olgu)'i digital dermatitis, \%16.57 (27 olgu)'si interdigital hiperplazi, \%15.95 (26 olgu)'i ökçe çürüğü, \%6.75 (11 olgu)'i tırnak çatlağı, \%3.68 (6 olgu)'i interdigital flegmon, \%2.45 (4 olgu)'i taban ülseri ve \%1.84 (3 olgu)'ü beyaz çizgi hastalığı oluşturdu. Hastalık tespit edilen olguların \%54.29 (152 olgu)'unda tırnak deformasyonu ile birlikte lezyon görülürken \%3.92 (11 olgu)'sinde sadece lezyon, \%41.79 (117 olgu)'un da da sadece tırnak deformasyonu saptandı. Topallık \%2.14 oranında sağ ön ayakta, \%4.29 oranında sol ön ayak, \%47.86 oranında sağ arka ayak, \%45.71 oranında sol arka ayakta görülmüştür. Arka ayaklardaki lezyonların daha çok lateral (\%55.73), ön ayakta ise daha çok medial tırnaklarda (\%61.11) yerleştiği saptanmıştır. Bu araştırmanın sonuçlarına göre 2016-2017 yılları arasında Ağrı ilinde sığırlarda ayak hastalıklarının yıllık prevalansı \%18.84 olarak belirlenmiştir.

Anahtar Kelimeler: Ayak hastalıkları, Prevalans, Sı̆̆ır, Ağrı ili.

\section{Determination of Prevalence of Foot Diseases in the Cattle in Ağrı Province}

\begin{abstract}
This study was conducted to determine the prevalence of foot diseases in cattle in Ağrı province. The study was carried out on a total of 1486 cattle of different breeds, ages and genders. Distribution of animals according to breeds were 34.66\% (515 cases) Brown Swiss, 30.96\% (460 cases) Simmental, 24.02\% (357 cases) indigenous breed and 10.36\% (154 cases) crossbreeds. Distribution of the cases among genders were $84.45 \%$ (1255 cases) females and $15.55 \%$ ( 231 cases) males. Foot diseases were found in 280 of 1486 cattle. Among the diseases determined were interdigital dermatitis in $29.45 \%$ ( 48 cases), digital dermatitis in $23.31 \%$ (38 cases), interdigital hyperplasia in $16.57 \%$ ( 27 cases), bruised sole in $15.95 \%$ ( 26 cases), fissured ungulae in $6.75 \%$ (11 cases), interdigital phlegmon in $3.68 \%$ (6 cases), sole ulcer in $2.45 \%$ (4 cases) and white line diseases in $1.84 \%$ (3 cases). In 11 cases (3.92\%) only lesions were observed while in 117 cases $(41.79 \%)$ only hoof deformities were determined. In 152 cases $(54.29 \%)$ both lesions and hoof deformities, were determined. Lameness were observed $2.14 \%$ in the right forefoot, $4.29 \%$ in the left forefoot, $47.86 \%$ in the right hind foot and $45.71 \%$ in the left hind foot. The lesions were found to be located more frequently in the lateral hoof of the hind foot $(55.73 \%)$ and in the medial hoof of the front foot (61.11\%). According to the results of this research, the annual prevalence of foot diseases in cattle in Ağrı province was determined as 18.84\% between 2016-2017.

Keywords: Foot disease, Prevalence, Cattle, Ağrı province.
\end{abstract}

\section{Giriş}

Sığır yetiştiriciliğinde karşılaşılan en önemli sağlık sorunlarından biride ayak hastalıklarıdır (Baran ve Kamiloğlu, 1997; Canpolat ve Bulut, 2003; Yalçın ve ark., 2010; Yavru ve ark., 1992; Yayla ve ark., 2012). Özellikle kültür ırkı sığır yetiştiriciliğinin yaygınlaşması ile ülkemizde ayak hastalıklarının giderek arttığı ve önemli ekonomik kayıplara yol açtığı rapor edilmektedir (Alkan ve ark., 1993; Anteplioğlu ve ark., 1992; Atasoy, 2003; İstek ve Durgun, 2004; Sağlıyan ve Ünsaldı, 2002; Yaylak, 2008). Ayak hastalıklarından kaynaklanan finansal kayıplar; laktasyon süresi ve süt veriminin azalması, canlı ağırlık artışında azalma, kilo kaybı, döl veriminin düşmesi, tedavi giderleri ve üretimden erken çıkarma olarak sıralanmaktadır (Görgül ve ark., 2002; Kamiloğlu, 2014; Keskin ve Durmuş, 2016; Özcan ve Pamuk, 2009; Özsoy ve Yücel, 1991; Yaylak, 2008). Ayak lezyonlarının görülme oranı sığırın ırkı, yetiştirme şekli, iklim ve coğrafi bölgelere göre değişiklikler göstermektedir (Canpolat ve ark., 2005; Güzel ve Erden, 2000; Ormancl ve Belge, 2001; Özcan ve Pamuk, 2009; Şındak ve ark., 2003). Genetik yatkınlık, yapı bozuklukları, mevsim, çevresel faktörler, yaş, laktasyon, hatalı besleme ve tırnak bozuklukları gibi nedenler ayak hastalıkları insidansı üzerine etkili olmaktadır (Alkan ve ark., 1993; Elma ve Kumandaş, 2015; Han ve ark., 2017; Özsoy ve Yücel, 1991; Yalçın ve ark., 2010). Ayak 
hastalıklarının prevalansı ile ilgili yapılan çalışmaların bölgede bulunan hastalıkların tespit edilmesi, bu hastalıkların sebepleri ve tedaviye yaklaşım şeklinin belirlenmesi ile veteriner hekim ve yetiştiricilere kolaylık sağlayacağı bildirilmektedir (Çeçen ve Görgül, 2007; Şındak ve ark., 2003; Yayla ve ark., 2012).

Bu çalışmada Ağrı ilinde sığırlarda görülen ayak hastalıkları prevalansının belirlenmesi ile koruyucu önlemler ve sağaltım yönünden yetiştiricilerin bilinçlendirilerek ekonomik kayıpların en aza indirilmesi amaçlanmıştır.

\section{Materyal ve Metot}

Bu çalışma; 2016-2017 yılları arasında Ağrı ilindeki ahır ve çiftliklerde ayak hastalıkları yönünden muayenesi yapılan farklı ırk, yaş, cinsiyet ve ağırlıkta 1486 sığır üzerinde yapıldı.

Araştırma süresince öncelikle ahır ve barınaklar kontrol edilerek tespit edilen eksiklikler hayvan sahiplerine bildirildi. İşletmelerde yapılan incelemelerde önce hayvanların ırkı, yaşı, cinsiyeti, bakım, beslenme ve ayakların anatomik yapısı incelenerek kayıtları tutuldu. Kayıtları tutulan ve ayak hastalıkları belirtisi gösteren hayvanlar detaylı incelemeye alındı. Semptom gösteren hayvanlar için öncelikle anamnez alınarak işleme başlanıldı. Anamnez ile hastalığın klinik seyrine göre evresi ve topallığın gruplandırılması belirlenmeye çalışıldı. Topallayan ayak tırnağının mekanik temizliğinden sonra; tırnak şeklinin düzgünlüğü, tırnak büyüklüğünün hayvanın cüssesine göre normal olup olmadığı, tırnaktaki maddi kayıplar, ayrılmalar, biçim değişiklikleri, fistüllerin varlığı, yumuşak ökçelerdeki ve korona bölgesindeki kızarıklık ve şişkinliklerin olup olmadığı araştırıldı. Ayak lezyonları görülen sığırların sayısı, cinsiyeti, ırkı, yaşı belirlenerek bulgular değerlendirildi.

\section{Bulgular}

Bu çalışma kapsamında değerlendirilen değişik ırk, yaş ve cinsiyetteki toplam 1486 sığırdan 280'ninde topallıkla karakterize ayak hastalıkları tespit edilerek prevalansı \%18.84 olarak belirlendi. Çalışmayı oluşturan hayvanların \%34.66 (515 olgu)'sını Montofon, \%30.96 (460 olgu)'sını Simental, \%24.02 (357 olgu)'sini yerli ve \%10.36 (154 olgu)'sını melez ırk oluşturdu. Ayak hastalığı saptanan olguların ırklara göre dağılımı ise \%44.29 (124 olgu)'u Montofon, \%32.14 (90 olgu)'ü Simental, \%13.21 (37 olgu)'i yerli ve \%10.36 (29 olgu)'sı melez ırk olarak belirlendi. Olguların cinsiyete göre dağılımları incelendiğinde \%84.45 (1255 olgu)'i dişi, \%15.55 (231 olgu)'i ise erkek idi. Hasta hayvanların \%79.29 (222 olgu)'nun dişi, \%20.71 (58 olgu)'inin de erkek hayvanlardan oluştuğu saptandı.

Hastalık en çok \%24.64 (69 olgu) oran ile 2 yaş sığırlarda görüldü. Bunu sırasıyla \%21.79 (61 olgu) oran ile 3 yaşı sığırlar, \%13.22 (37 olgu) oran ile 5 yaşlı sığırlar, \%12.14 (34 olgu) oran ile 4 yaşlı sığırlar, \%9.64 (27 olgu) oran ile 1 yaşlı sığırlar, \%5 (14 olgu) oran ile 6 yaşlı sığırlar, \%4.29 (12 olgu) oran ile 7 yaşlı sığırlar, \%3.21 (9 olgu) oran ile 8 yaşlı sığırlar, \%3.21 (9 olgu) oran ile 9 yaşlı sığırlar ve \%2.86 (8 olgu) oran ile 10 yaşlı sığırlar takip etti. Hastalık en çok 1-5 yaş arası sığırlarda (minimum1maksimum10) görüldü.

Bu çalışmada rastlanılan hastalıklar interdigital dermatitis \%29.45 (48 olgu) (Şekil 1b), digital dermatitis \%23.31 (38 olgu), interdigital hiperplazi \%16.57 (27 olgu) (Şekil 1a, 2a, 2b), ökçe çürüğü \%15.95 (26 olgu) (Şekil 3c), tırnak çatlağı \%6.75 (11 olgu), interdigital flegmon \%3.68 (6 olgu) (Şekil 3a), taban ülseri \%2.45 (4 olgu) (Şekil 3b), beyaz çizgi hastalığı \%1.84 (3 olgu) oranında gözlemlendi. Hastalık tespit edilen olguların \%93.25 (152 olgu)'inde tırnak deformasyonu ile birlikte lezyon görülürken \%6.75 (11 olgu)'inde sadece lezyon görüldü.

Ayak hastalığı tespit edilen 280 olgudan \%54.29 (152 olgu)'unda ayak hastalığı ile birlikte tırnak deformasyonu, \%3.92 (11 olgu)'sinde ayakta sadece lezyon ve \%41.79 (117 olgu)'unda da sadece tırnak deformasyonu saptandı. Taramalar sırasında hem lezyonla birlikte görülen, hem de sadece tırnak deformitesi tespit edilen olguların dağılımı ise sivri tırnak \%43.49 (117 olgu), tirbüşon tırnak \%27.88 (75 olgu) (Şekil 1a), yayvan ve geniş tırnak \%17.10 (46 olgu), makas tırnak \%6.69 (18 olgu), küt tırnak \%3.35 (9 olgu) ve ayrık tırnak \%1.49 (4 olgu) (Şekil 1b) oranında gözlemlendi.

Topallığın \%2.14 (6 olgu) oranında sağ ön ayakta, \%4.29 (12 olgu) oranında sol ön ayak, \%47.86 (134 olgu) oranında sağ arka ayak ve \%45.71 (128 olgu) oranında sol arka ayakta olduğu görüldü. Arka ayaklardaki lezyonların büyük çoğunluğunun lateral (\%55.73), ön ayakta ise daha çok medial tırnaklarda (\%61.11) lokalize olduğu tespit edildi.

\section{Tartışma ve Sonuç}

Sığırlarda ayak hastalıklarının prevalansının belirlenmesi amacıyla yapılan çalışmalarda, nedenlerin ortaya çıkarılması ve tedavi 
seçeneklerinin sunulmasıyla hem veteriner hekimlere hem de yetiştiricilere büyük katk sağlanacağı rapor edilmektedir (Çeçen ve Görgül, 2007; Şındak ve ark., 2003; Yayla ve ark., 2012). Bu amaçla ülkemizde yapılan çalışmalarda bölgelere göre ayak hastalıkları prevalansı, İstanbul ve Tekirdağ bölgesinde \%18.6 (Yücel, 1982), Konya bölgesinde \%68 (Yavru ve İzci, 1988), Van ve yöresinde \%26.31 (Alkan ve ark., 1993), Tunceli ve yöresinde \%12 (Sağlıyan ve Ünsaldı, 2002), Elazığ yöresinde \%17 (Canpolat ve Bulut, 2003), Erzurum yöresinde \%22.72 (Atasoy, 2003), Muş ve yöresinde
\%14.16 (İstek ve Durgun, 2004), Kars ve yöresinde \%12.08 (Yayla ve ark., 2012), Gaziantep ve yöresinde \%11.14 (Keskin ve Durmuş, 2016), Sivas ve yöresinde \%38.77 (Yurdakul ve Şen, 2018) gibi oldukça değişken ancak, çalışmaların yapıldığı bölgeler itibariyle, yüksek oranlarda ayak hastalığına rastlandığı bildirmektedirler. Bu çalışmada Ağrı ilinde sığırlarda ayak hastalıklarının prevalansı \%18.84 olarak belirlenmiştir. Bu oran Türkiye'nin benzer iklim ve coğrafi konumunda olan illerdeki sığırların ayak hastalıkları prevalansına yakındır.

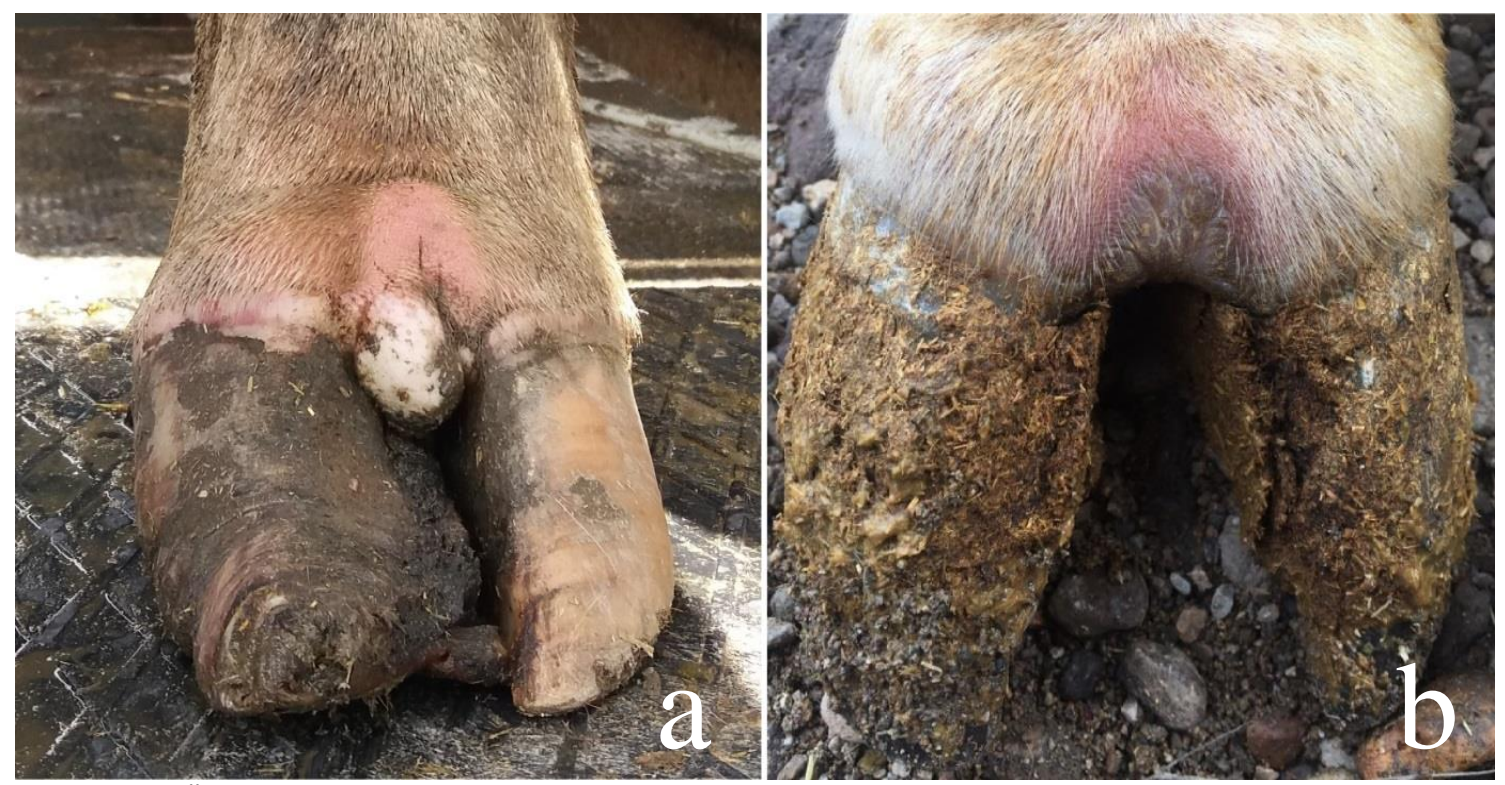

Şekil 1. (a) Üç yaşlı dişi sığırda, interdigital hiperplazi (limaks, tilom, interdigital fibroma) ile ucu tırnakçı adlı ampiriklerce kesilmiş tirbüşon tırnak ve (b), dört yaşlı dişi sığırda interdigital dermatitis ile ayrık tırnak görünümü.

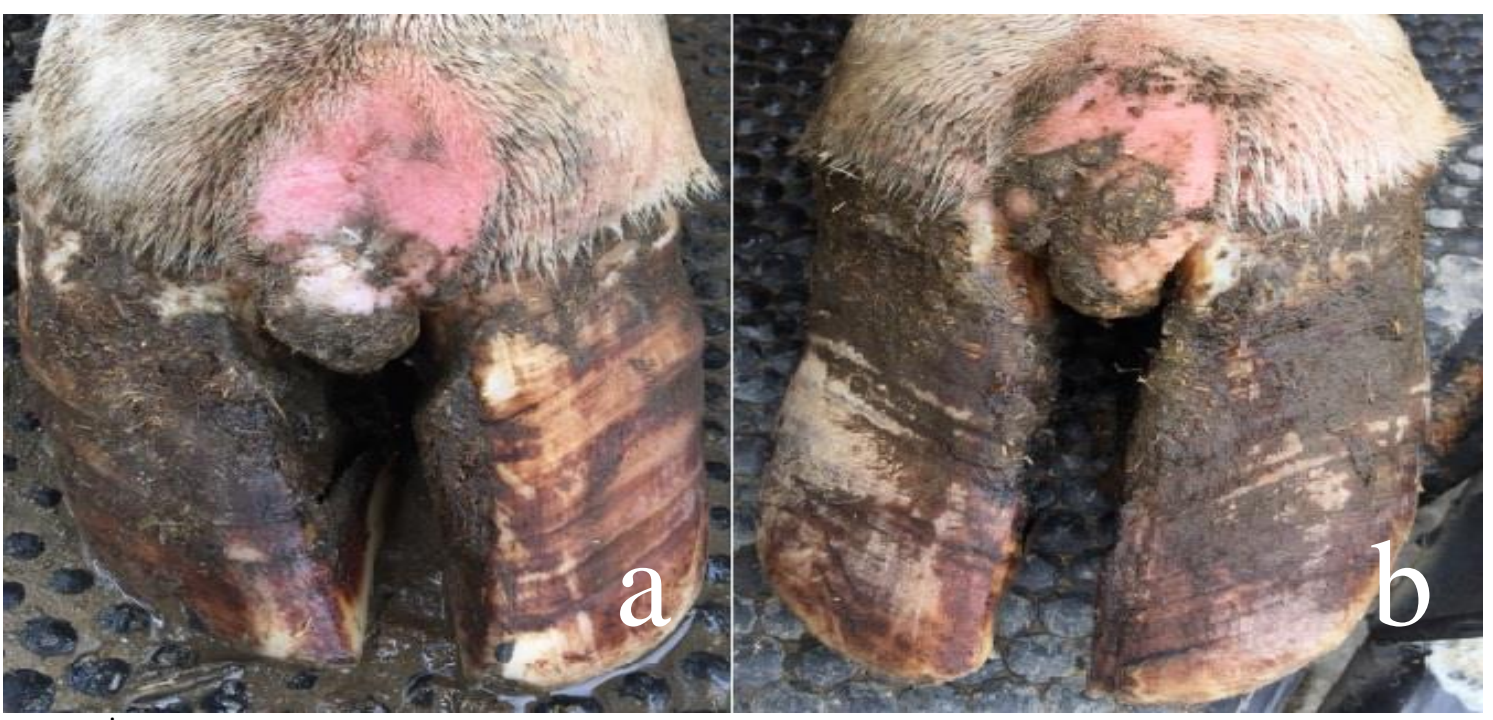

Şekil 2. İki yaşlı dişi sığırda (a), sağ ve (b), sol ön ayaklarda interdigital hiperplazinin klinik görünümü ve hatalı tırnak kesimi. 


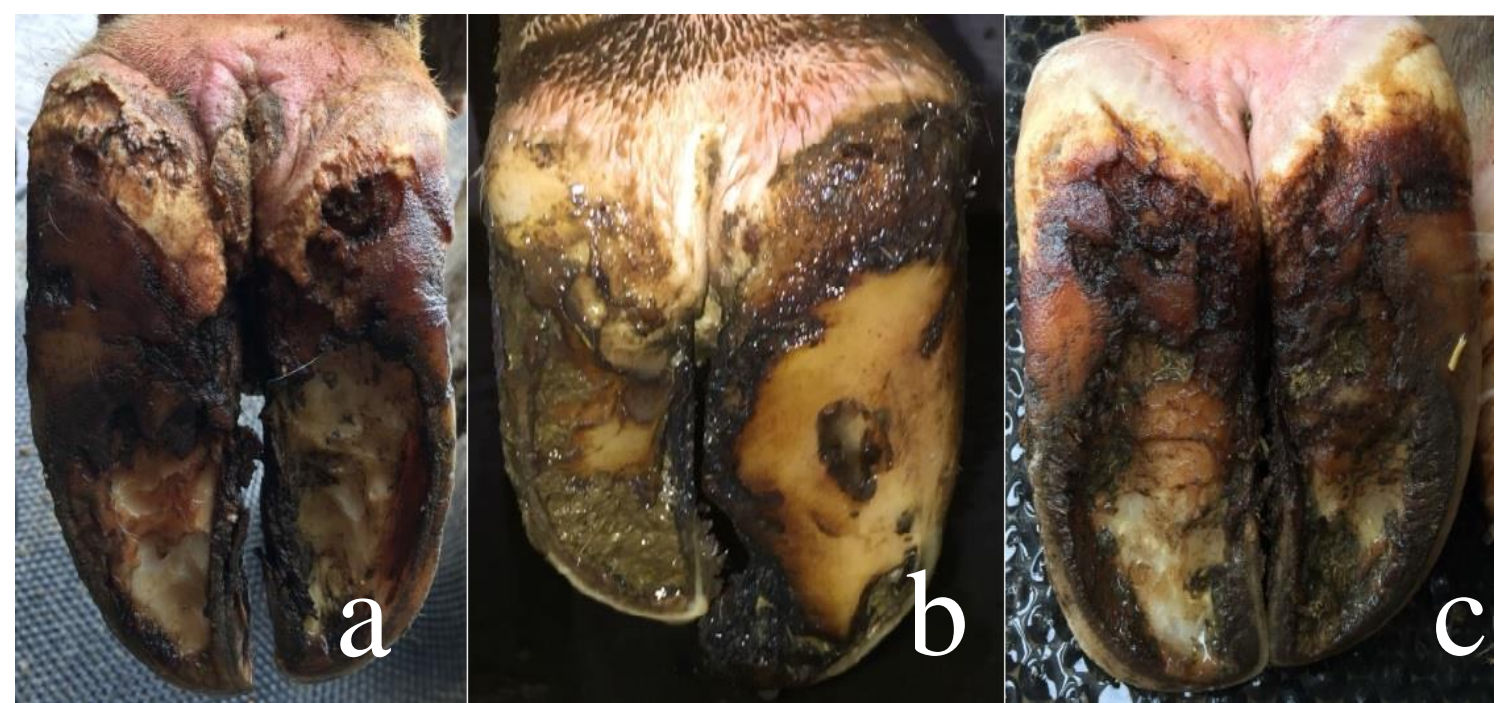

Şekil 3. (a), iki yaşı dişi sığırda interdigital flegmon (b), bir yaşlı düvede taban ülseri (Rusterholz ulkusu) ve (c), iki yaşlı dişi sığırda ökçe çürüğünün görünümü.

Sığırlarda ayak hastalıklarının yerli ırka göre kültür ırklarında daha yaygın görüldüğü bildirilmektedir. Bunun nedeni olarak ta kültür ırklarının yerli ve melez ırklara göre daha fazla canlı ağırlığa sahip olması, yüksek verim özelikleri ve Türkiye'deki hastalıklara karşı daha dirençsiz olmasına bağlanmaktadır (İstek ve Durgun, 2004; Özcan ve Pamuk, 2009; Ünsaldı ve Durmuş, 1999; Yayla ve ark., 2012; Yurdakul ve Şen, 2018). Türkiye'nin farklı bölgelerinde sığır ayak hastalıkları prevalansının belirlenmesi amacıyla yapılan çalışmalarda hayvan ırklarının coğrafi dağılımı farklılık göstermekle birlikte kültür ırklarında ayak hastalıkları oranının daha fazla olduğu saptanmıştır. Görgül (1988) çalışmasında ayak lezyonlarının ırklara göre dağılımını Holştayn \%69.52, Montofon $\% 24.76$, Jersey \%0.95, yerli \%1.92, melez \%2.85 olarak belirlemiştir. İstek ve Durgun (2004) çalışmalarında Holştayn \%23.13, Simental \%19.56, Montofon \%14.74, melez \%12.20, yerli ırk sığırlarda ise \%10.26 oranında bildirilmişlerdir. Özcan ve Pamuk (2009) çalışmalarında Holştayn'larda \%47.17, Montofon'larda \%17.44, yerli ırkta \%10.26, Simental'lerde \%12.30 ve melez irkta \%12.83 oranında saptamışlardır. Yayla ve ark. (2012) Simental \%18.51, melez \%11.13, Montofon \%10.81 ve yerli ırk \%8.45 olarak belirlemişlerdir. Keskin ve Durmuş (2016) Holştayn \%65.73, Simental \%27.23, Montofon \%5.16, yerli \%1.41 ve melez ırkta \%0.47 oranında görüldüğünü bildirmektedirler. Yurdakul ve Şen (2018) Holştayn \%60.61, Simental \%56.06, Montofon \%29.67, Melez \%23.75 ve Yerli ırk sığırlarda \%20,59 oranında bildirmişlerdir. Bu araştırmada hastalık Montofon ırkta \%44.29, Simental ırkta \%32.14, yerli ırkta \%13.21 ve melez ırkta \%10.36 oranında görülmüştür. Bu çalışmanın bulgularıyla da ayak hastalıklarının kültür ırklarında daha yüksek oranlarda görüldüğü ortaya konmuştur.

Sığırlarda ayak hastalıkları üzerine yapılan çalışmalarda hastalıkların cinsiyete göre dağılımlarının belirlendiği araştırmalarda; Özsoy ve Yücel (1991)'in bulgularında hasta hayvanların \%68.3 'nün dişi, \%36.2'sının erkek, Alkan ve ark. (1993)'nın çalışmalarında \%86.36'sının dişi, \%13.64'ünün erkek, Ünsaldı ve Durmuş (1999)'un bulgularında \%97.3'nün dişi, 2.7\%'sinin erkek, Sağlıyan ve Ünsaldı (2002)'nın çalışmalarında \%68.90'nın dişi, \%31.10'unun erkek, İstek ve Durgun (2004)'nun çalışmalarında 79.31\%'nın dişi, \% 20.69'nun erkek, Yayla ve ark. (2012)'nın çalışmalarında \%51.8'inin dişi, \%48.2 'sinin erkek, Yurdakul ve Şen (2018)'in çalışmalarında \%71.62'sinin dişi, \%28.38'nin erkek hayvanlarda görüldüğü bildirilmiştir. Bu çalışmada ise cinsiyete göre dağılımları \%79.29 dişilerde, \%20.71 ise erkeklerde görüldüğü saptandı ve dişilerde erkeklerden daha yaygın görülmesi diğer çalışmaların sonuçlarıyla uyumluydu. Ayak hastalıklarının dişi hayvanlarda daha yüksek oranlarda görülmesi hayvanların verim özelliklerine bağlanabilir. Süt ineklerinin laktasyon evrelerinde tırnak mineral kompozisyonundaki değişimlere, gebeliğin ileri dönemlerinde vücut ağırlığının artışına bağlı olarak tırnaklara daha fazla yük binmesi ile ilişkilendirilebilir. Aynı zamanda bu çalışmada Ağrı ilinde dişi hayvan popülasyonun fazlalığına bağlanabilir. Erkek hayvanların kasaplık edilmesi ve ekonomik değerlerinden dolayı diğer illere satılması Ağrı ilinde dişi hayvan popülasyonunu arttırmakta ve hastalıkların dişi hayvanlarda daha yüksek oranlarda görülmesine yol açmaktadır. 
Ayak hastalıklarının etiyolojisinde yaşın önemli bir faktör olduğu hastalığın daha çok 3-7 yaş arası sığırlarda görüldüğü bildirilmektedir (Keskin ve Durmuş, 2016). Özsoy ve Yücel (1991) 1-5 yaş arasında, İstek ve Durgun (2004) 4 ve 6 yaşındaki sığırlarda, Yayla ve ark. (2012) ortalama 2.14, Keskin ve Durmuş (2016) en fazla 3 yaşındaki sığırlarda ayak hastalıklarının meydana geldiğini bildirmektedirler. Bu çalışmada da hastalıkların en çok 1-5 yaş arası sığırlarda şekillendiği belirlendi. Hastalık en çok \%24.64 oran ile 2 yaşlı sığırlarda görüldü. Bu çalışmada da ayak hastalıklarının yüksek oranda genç hayvanlarda görülmesi Yayla ve ark. (2012)'nın bildirdiği gibi, şap hastalığının kültür ırkı sığırlarda ve gençlerde çok çabuk ve şiddetli seyretmesine bağlanabilir. Aynı zamanda bu çalışmada Ağrı ilinde ekonomik açıdan verimliliğini yitirmiş olan yaşlı sığırların kesime sevk edilmesi hastalıkların genç hayvanlarda daha sıklıkla görülmesine yol açmıştır.

$\mathrm{Bu}$ araştırmada belirlenen ayak hastalıkları içerisinde ilk sırayı ayak derisi hastalıkları almıştır. Bunu sırasıyla \%29.45 oran ile interdigital dermatitis, \%23.31 oran ile digital dermatitis ve \%16.57 oran ile interdigital hiperplazinin izlediği görüldü. Ayak hastalığı saptanan 163 olgudan 119 (\%73.01)'unun ayak derisi hastalığı olduğu saptandı. Atasoy (2003)'unda bildirdiği gibi ayak derisinde lezyonların oluşumu büyük oranda basit travmatik yaraların zamanında tedavi edilmeyip, tırnak bakımı, ahır yapısı ve hijyenine gerekli önemin verilmemesinin en önemli etken olduğu yapılan gözlemlerde saptanmıştır. Deri hastalıklarından sonra \%15.95 oran ile hastalıklar arasında en fazla ökçe çürüğünün görülmesi ise deri lezyonlarının ileri aşamasında ökçenin kornu tabakasında lezyonlara neden olduğu bununda ökçe erozyonuna yol açtığ ayrıca nemli ve hijyenik olmayan ahır şartlarının neden olduğu şeklinde yorumlanabilir.

$\mathrm{Bu}$ çalışmada tırnak deformiteleri ve tırnak deformiteleri ile birlikte görülen ayak hastalıklarındaki tırnak deformitelerinin toplam sayısı 269'dur. Deformite oranları; sivri tırnak \%43.49 (117 olgu), tirbüşon tırnak \%27.88 (75 olgu), yayvan ve geniş tırnak \%17.10 (66 olgu), makas tırnak \%6.69 (18 olgu), küt tırnak \%3.35 (9 olgu), ayrık tırnak \%1.49 (4 olgu) oranında belirlendi. Bu çalışmada ayak hastalığı saptanan 280 olgunun 152'sinde ayak hastalığı ile birlikte tırnak deformasyonu görüldü. Tırnak deformitelerinin ayak hastalıkları içerisinde \%54.29 gibi yüksek oranda görülmesi ayak hastalıklarının oluşmasında deforme tırnak yapısının önemli rol oynadığı bundan önceki araştırmacıların bulguları ile benzerdi (Alkan ve ark., 1993; Elma ve Kumandaş, 2015; Han ve ark., 2017; Özcan ve Pamuk, 2009; Samsar ve ark., 1977; Yavru ve ark., 1992; Yayla ve ark., 2012; Yurdakul ve Şen,
2018). İstek ve Durgun (2004) ile Han ve ark. (2017)'nın da belirttiği gibi, deforme tırnak sayısının yaygınlığı hayvanların uzun kış şartları nedeniyle ahırlarda kapalı tutulup, yeterince gezdirilmediği, yetiştiricilerin tırnak bakımına gereken önemi vermediği ve tırnak bakımı yapan kişilerinde veteriner hekim olmamasından kaynaklandığı gözlemlendi.

Sığırlarda ön ayaklarda medial, arka ayaklarda lateral tırnaklara daha fazla ağıllık binmektedir. Bu nedenle sığırlarda ayak hastalığı genelde ön ayaklarda medial, arka ayaklarda lateral tırnakta meydana gelmektedir (Alkan ve ark., 1993; Keskin ve Durmuş, 2016; Özsoy ve Yücel, 1991; Salcı, 2015; Yavru ve ark., 1992; Yayla ve ark., 2012). Bu araştırmada deforme tırnak ve deforme tırnak yapısı ile birlikte ayak hastalığı şekillenen tırnak sayısı ve ayak hastalıkları toplamı 280'dir. Bunların \%6.43 (18 olgu)'ü ön, \%93.57 (262 olgu)'si arka ayakta olmak üzere \%53.57 (150 olgu)'si lateralde, 35.72 (100 olgu)'i medialde ve 10.71 (30 olgu)' $i$ ise bilateral olarak şekillenmiştir. Bu araştırmanın sonuçları bu konuda daha önce yapılmış araştırmacıların sonuçlarını destekler niteliktedir (Atasoy, 2003; Canpolat ve Bulut, 2003; Özcan ve Pamuk, 2009; Yayla ve ark., 2012; Yurdakul ve Şen, 2018). Bu çalışmada hastalığın arka ayaklarda ve özellikle lateral tırnaklarda görülmesinin sebebi olarak, literatürlerden de bildiğimiz gibi arka ayaklara daha fazla yük binmesi sonucu oluştuğu düşünülmektedir.

Sonuç olarak, bu çalışmada Ağrı ilinde sığırlarda görülen ayak hastalıkları prevalansının belirlenerek literatüre kazandırılması amaçlanmıştır. Ayak hastalığı prevalansının \%18.84 olarak belirlendiği bu araştırmada ayak lezyonlarının büyük oranda bilinçsiz yetiştiricilikten kaynaklandığı tespit edilmiştir. Bu nedenle, işletmelerde bakım ve barındırma koşullarının iyileştirilmesi, ayak banyolarının kullanılması, düzenli tırnak kesimi ve bakımının yanı sıra koruyucu önlemler ve sağaltım yönünden yetiştiricilerin bilinçlendirilmesinin ayak hastalıkları prevalansının düşürülmesine katkı sağlayacağı sonucuna varılmıştır.

\section{Kaynaklar}

Alkan I, Boynukara B, Celep M, 1993: Van ve yöresinde sığır ayak hastalıklarının yayılışı, nedenleri ve sağaltımı üzerine bir araştırma. YYÜ Vet Fak Derg, 4(1-2), 87-95.

Anteplioğlu H, Akın F, 1978: Kliniğimizde sığırlarda rastladığımız topallıklar ve bunların nedenlerine toplu bir bakış. AÜ Vet Fak Derg, 25(1), 144-162.

Atasoy N, 2003: Erzurum yöresinde süt sığırlarında görülen ayak hastalıklarının insidansı ve bunların sağaltımı. YYÜ Vet Fak Derg, 14(1), 1-5. 
Baran V, Kamiloğlu A, 1997: Sığırlarda topallığın belirlenmesinde yararlanılan tanı kontrol çizelgeleri. Kafkas Univ Vet Fak Derg, 3(2), 247-249.

Canpolat I, Bulut S, 2003: Elazığ ve çevresinde sığırlarda görülen ayak hastalıklarının insidansı üzerine gözlemler. Fü Sağ Bil Derg, 17(3), 155-160.

Canpolat I, Bulut S, işsler CT, Timurkan S, 2005: Effect of biotin or ethylendiamine dihyriodidie suplementation on claw lessions in cattle. Doğu Anadolu Araştırmaları Dergisi, 3(2), 56-59.

Çeçen G, Görgül OS, 2007: Bursa yöresindeki bir işletmede, sağmal süt sığırı sürüsünde karşılaşılan topallıkların değerlendirilmesi. Veteriner Cerrahi Derg, 13(1), 5-10.

Elma E, Kumandaş A, 2015: Sığırlarda tırnak kesimi. Türkiye Klinikleri J Vet Sci Surg-Special Topics, 1(1), 73-77.

Görgül OS, 1988: Sığırlarda tırnak bakımı ve ayak hastalıklarının sebep ve sonuç ilişkileri. Profesörlük Takdim Tezi, Uludağ Üniv Vet Fak, Bursa.

Görgül OS, Kahraman MM, Çeçen G, Akkoç A, Gül NY, Sevimli A, 2002: Sığırlarda digital ve interdigital dermatitis'lerde klinik tanı, sağaltım ve histopatolojik bulgular. Uludağ Univ J Fac Vet Med, 21, 115-124.

Güzel N, Erden H, 2000: Aydın yöresi sığırcılık işletmelerinde ayak hastalıklarının dağılımı. Veteriner Cerrahi Derg, 6(3-4), 8-10.

Han MC, Sağııyan A, Polat E, 2017: Sığırlarda ahır zemin tiplerinin ayak hastalıkları ve tırnak deformasyonları üzerine etkilerinin araştırılması. Harran Üniv Vet Fak Derg, 6(1), 19-24.

İstek Ö, Durgun T, 2004: Muş ve yöresindeki sığırlarda görülen ayak hastalıklarının prevalansı üzerine araştırmalar. Doğu Anadolu Bölgesi Araştırmaları, 39-47.

Kamiloğlu A, 2014: Çiftlik Hayvanlarında Ayak Hastalıkları. 1. Baskı., Medipres, Ankara, Türkiye.

Keskin E, Durmuş AS, 2016: Gaziantep ve yöresinde gözlenen sığır ayak hastalıklarının insidansı ve tedavileri üzerine gözlemler. FÜ Sağ Bil Vet Derg, 30(3), 181-186.

Ormancı S, Belge A, 2001: Van ve yöresinde süt sığırlarında ayak hastalıklarının nedenleri, dağılımı ve sağaltımı üzerinde çalışmalar. YYÜ Sağ Bil Derg, 7(1-2), 139-145.

Özcan S, Pamuk K, 2009: Afyonkarahisar ve çevresinde sığır ayak hastalıklarının insidansı. Kocatepe Vet $J$, 2(2), 15-19.

Özsoy S, Yücel R, 1991: İstanbul ve yöresindeki kültür ırkı sığırlarda ayak hastalıklarının etiyoloji, patogenezis ve sağaltımları üzerine karşılaştırmalı araştırmalar. istanbul Üniv Vet Fak Derg, 17(1), 93-108.
Sağlıyan, A, Ünsaldı, E. 2002: Tunceli ve yöresindeki sığırlarda karşılaşılan ayak hastalıklarının insidansı üzerine gözlemler. Fü Sağ Bil Derg, 16(1), 47-56.

Salcı H, 2015: Sığırlarda ayak hastalıklarının radyolojik ve biyomekanik ilişkilendirilmesi: 13 olguluk bir ön çalışma. Uludağ Univ J Fac Vet Med, 34(1-2), 89-93.

Samsar E, Akın F, Güzel N, Koç B, Ersümer C, Yavru N, 1977: Ankara bölgesi süt ineklerinin ekstremitelerinde görülen sirurjikal hastalıklar ve bunların hazırlayıcı nedenleri. Veteriner Hekimliği Dergisi, 47, 15-24.

Şındak N, Keskin O, Selçukbiricik H, Sertkaya H, 2003: Şanlıurfa ve yöresinde sığır ayak hastalıklarının prevalansı. YYÜ Vet Fak Derg, 14(1), 14-18.

Ünsaldı E, Durmuş AS, 1999: 1994-1998 yılları arasında kliniğimize gelen sığırlarda gözlenen ayak hastalıkları ve sağaltımları. FÜ Sağ Bil Derg, 13, 405-412.

Yalçın C, Sarı̈zkan S, Yıldız AŞ, Günlü A, 2010: Burdur, Kırklareli ve Konya IIl'lerindeki süt sığırcılığı işletmelerinde ayak hastalıklarından kaynaklanan finansal kayıplar. Ankara Üniv Vet Fak Derg, 57, 99104.

Yavru N, Koç Y, Elma E, Erer H, Özkan K, İzci C, Kaya Z, 1992. Konya bölgesinde sığır topallıklarına neden olan ayak hastalıkları üzerine radyolojik ve histopatolojik incelemeler. SÜ Vet Fak Derg, 8(1), 38.

Yavru N, İzci C, 1988: Konya bölgesinde sığır topallıklarına neden olan ekstremite hastalıklarının sınıflandırılması ve bu hastalıkların tanısında radyolojinin önemi. Doğa Vet Hay Derg, 13(3), 283293.

Yayla S, Aksoy Ö, Kılıç E, Cihan M, Özaydın I, Ermutlu CŞ, 2012: Kars ve yöresinde sığırların bakım ve barındırma koşulları ile ayak hastalıkları arasındaki ilişkinin değerlendirilmesi. Harran Üniv Vet Fak Derg, 1(1), 22-27.

Yaylak E, 2008: Süt sığırlarında topallık ve topallığın bazı özellikleri. Hay. Üretim, 49, 47-56.

Yurdakul i, Şen i, 2018: Sivas ve yöresinde sı̆̆ır ayak hastalıkları prevalansının belirlenmesi. Harran Üniv Vet Fak Derg, 7(1), 51-55.

Yücel R, 1982: İstanbul ve Tekirdağ bölgesindeki sığırlarda görülen ayak hastalıklarının toplu bir değerlendirilmesi. İstanbul Üniv Vet Fak Derg, 1, 4761.

Yazışma adresi: Selvinaz YAKAN

Ağrı İbrahim Çeçen Üniversitesi, Eleşkirt Celal Oruç Hayvansal Üretim Yüksek Okulu, Hayvan Sağlığı Anabilim Dalı, Ağrı-Türkiye.

E-mail: syakan@gmail.com 